\title{
Effect of Website Quality and Experience on Performance Expectancy Trough E-Commerce X In Indonesia
}

\author{
Oliandes Sondakh \\ Universitas Pelita Harapan
}

\begin{abstract}
In 2019, the number of internet users in Indonesia is projected to reach 175 million, or about $65.3 \%$ of the total population of Indonesia which is estimated to reach 268 million. The survey results published by the Indonesian Internet Service Providers Association (2016) show that as many as 123.5 million Indonesians use the internet to access commercial content. The high level of access to commercial content in Indonesia is a great opportunity to start e-commerce. Research conducted by Loureiro and Amorim (2017) shows that perceived website quality and experience greatly influences the judgment of a user on e-commerce performance expectancy. This research uses 130 loyal customers from well-known e-commerce in Indonesia. Non probability sampling with purposive sampling technique is used to collect data to ensure the suitability of respondents with the purpose of the study. To be a sample, respondents must have used ecommerce at least 2 times in the past 1 month. Based on the results of the study, it was concluded that website quality had a significant effect on experience, but was not significant for performance expectancy; experience has a significant effect on performance expectancy.
\end{abstract}

Keywords: Perceived Website Quality, Experience, Performance Expectancy.

\section{Introduction}

In 2019, the number of internet users in Indonesia is projected to reach 175 million, or around $65.3 \%$ of the total population of Indonesia which is estimated to reach 268 million. The increase in internet users is mainly supported by the increasingly widespread use of smart phones (smartphones) in Indonesia. The projected number increased 32 million, or $22.37 \%$ compared to the last survey of the Indonesian Internet Service Providers Association (APJII) in 2017 which recorded 143 million internet users (https://id.beritasatu.com).

The results of a survey published by the Indonesian Internet Service Providers Association (2016) show that as many as 123.5 million Indonesians use the internet to access commercial content. Commercial content here is categorized into three, namely online shop, personal business, and other commercial content. As for the percentage of access for these three categories, there are $62 \%$ onlineshop; personal business as much as $34.2 \%$; and other commercial content as much as 3.8\%. In addition, through the results of the 2016 APJII survey it is known that as many as $63.5 \%$ of the number of internet users in Indonesia in 2016, have made online transactions.

The high level of access to commercial content in Indonesia is a great opportunity to start e-commerce. According to Pearson (2008), electronic commerce or often referred to as e-commerce is a business process that is carried out by utilizing the use of communication and computer networks.

Data released by the Frost \& Sullivan research bureau in 2013 shows that Indonesia is one of the countries with the largest e-commerce market growth with an average growth of $17 \%$ per year (http://tekno.liputan6.com). With the characteristics of the market in Indonesia that continues to innovate, the Indonesian e-commerce industry is predicted to reach a value of US \$ 130 billion or around $\mathrm{Rp} 1.7$ quadrillion by 2020 (https://id.techinasia.com). In other words, the business of buying and selling online is considered as a potential business for Indonesia in the future.

Research conducted by Loureiro and Amorim (2017) shows that perceived website quality and experience greatly affect a user's assessment of the performance expectancy of an e-commerce. To assess the quality of 
performance of an e-commerce, users will judge it first in terms of the external appearance that is on the website. Users assume that the quality of the website reflects how the website's performance will be. So the better the quality of the website according to the user, the higher the performance expectancy perceived by the user.

Furthermore, experience influences one's interest in online shopping, both past online shopping experiences and experience in using technology. The better the user experience, the better the performance expectancy that the user has.

\section{Literature Review}

\section{Perceived Website Quality}

Zeithaml et al. (2002) revealed that website quality is the quality of a site's services provided to its customers. Website quality is the quality of the technical dimensions, content, and appearance of a website that is considered important by the user so that it also influences the user's behavior and evaluation of the website (Al-Qeisi et al., 2014).

Olsina et al. (2006) revealed that website quality from the user's perspective is the process of evaluating the quality of website content in terms of several things, such as navigation, beauty, function, and other things. Website quality is defined as an evaluation given by users regarding the functioning of website features in meeting their needs and is a reflection of the overall superiority of the website (Chang and Chen, 2008; Amorim and Loureiro, 2017). According to Yoo and Donthu (2001), a good quality website is a website that provides ease of use, aesthetic design, processing speed, and security of use.

\section{Experience}

Thompson and Kolsky (in Terblanche, 2004) revealed that experience is the accumulation of all events that are realized by customers. Experience is an internal and subjective customer response that arises as a result of direct and indirect interaction with the company (Meyer and Schwager, 2007). Experience is a customer's interpretation of their interactions with a brand (Frow and Payne, 2007).

According to Robinnete and Brand (2008), experience is the experience that customers feel about a product or service that it uses. Gentile, Spiller, and Noci (2007) define experience as a set of interactions between customers and products, companies, and parts of organizations where these interactions cause reactions that will determine how customers act in the future.

According to Shaw and Ivens (2002), experience is defined as the result of customer assessments related to performance and emotions arising from the use of a product where this assessment will affect every interaction he does with the company at the next moment.

Rini (2009) suggests that experience is the involvement of the five senses, hearts and minds of customers, which can place the purchase of products or services in contexts that are important in their lives. Experience is the embodiment of a brand that encompasses all interactions between companies and customers (Watkins, 2007).

\section{Performance Expectancy}

According to Parasuraman et al. (1990), performance expectancy is the ideal standard of performance held by customers. Performance expectancy is the degree to which a person hopes that the use of a system will create benefits in terms of performance in his work (Venkatesh et al., 2003; Ghalandari et al., 2012). Jati (2012) revealed that performance expectancy is someone who believes that the use of a system or technology will be very useful and can improve the performance and work performance it does.

Performance expectancy is an individual's belief that his performance will improve if he uses technology (Agustina, 2013). Furthermore Venkatesh et al. (2003) states that performance expectancy is built from the construct of perceived usefulness. Davis et al. (1992) defines perceived usefulness as the perception a customer has of a system, which is the result of an experience he has experienced. Perceived usefulness is an individual's level of confidence related to the extent to which the use of new technology will improve performance (Mathwick et al., 2001). 
Tan and Teo (2000) state that perceived usefulness is an important factor that determines the level of adoption of an innovation system. So it can be concluded that performance expectancy is an individual's beliefs related to the use of a technology that will improve performance where the performance expectancy is fulfilled or not, will affect his interest in adopting a new system.

\section{Research Framework}

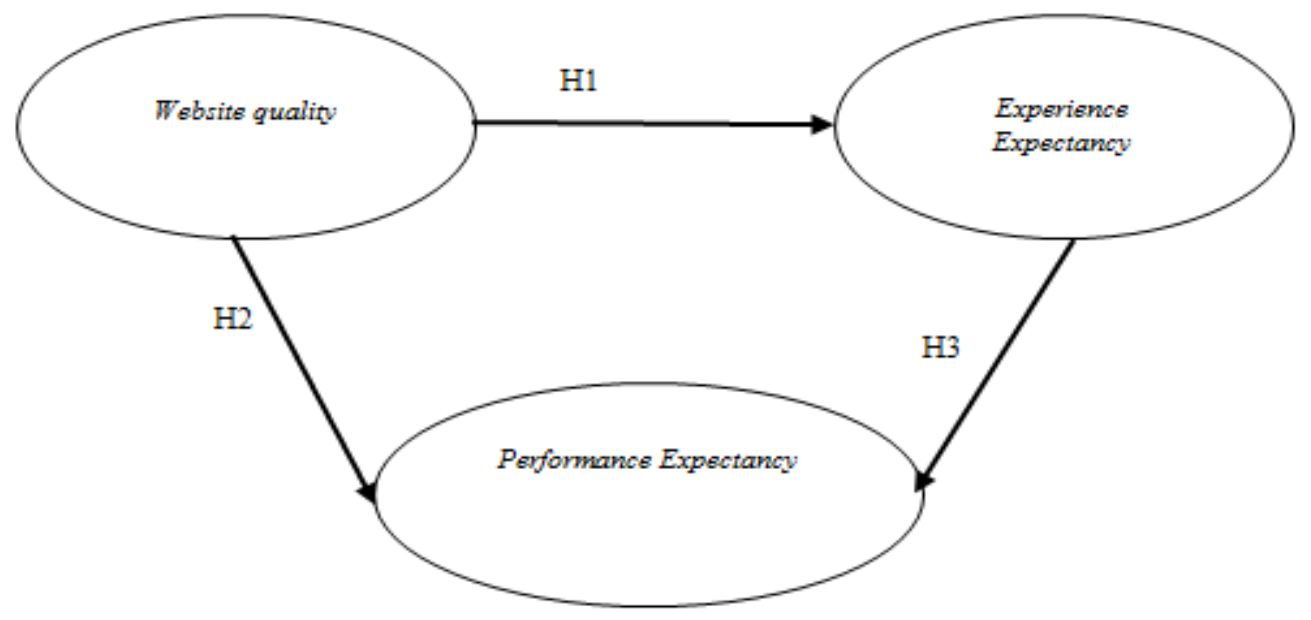

Figure 1: Research Framework

According to van Iwaarden et al. (2004), the visual appeal and content of a website affect an individual's perception of the usability, enjoyment, and ease of use of the site. In this case, visuals and content provided by a website are seen as a reflection of quality. So that the more a site has a visual appeal and content that is considered good in the eyes of the public, the more the site is seen to provide good experience, the more useful so that the expectations of the performance of the community related to the site will increase.

Thus the following hypotheses can be drawn:

H1: Perceived website quality have significant effect on experience.

$\mathrm{H} 2$ : Perceived website quality have significant effect on performance expectancy.

According to Dishaw et al. (2002), Johnson and Marakas (2000), the experiences of an individual influence the expectations of good performance expectations. The pleasant or bad experience of a person will influence his expectation that for the system he uses in the next moment, it will be better. According to Agarwal and Prasad (1999) and Jiang et al. (2000), one's internet experience influences one's interest in using a system. The high level of knowledge and the wealth of experience around the internet will make it easier for someone to use and adopt a new system.

Thus the following hypotheses can be drawn:

H3: Experience has significant effect on performance expectancy.

\section{Research Method}

A quantitative study, consistent with the quantitative paradigm, is an inquiry into behavioral problems, based on theory testing consisting of variables, measured by numbers, and analyzed by statistical procedures, to determine whether the predictive generalizations of the theory apply. The research design used in this study was cross sectional with a low intervention rate because it used a questionnaire as primary data. Five Likert scales are used to measure and determine respondents' perceptions.

This study uses 130 loyal customers from well-known e-commerce in Indonesia. Non-probability sampling with purposive sampling technique is used to collect data to ensure the suitability of respondents with the research objectives. To be a sample, respondents must have used e-commerce at least 2 times in the past 1 month.

To test the hypothesis, linear regression is used as the main analysis method, because it can analyze the relationship between independent and dependent variables. In this study, the regression coefficient of the 
independent variable (Beta) is used to determine the direction of the relationship between the independent and dependent variables; Beta> 0 shows a positive relationship. The level of acceptance of the hypothesis is determined by t-sig; t-sig $<0.05$ indicates the level of significance of the relationship at the $95 \%$ confidence level.

\section{Findings and Discussion}

\section{Findings}

Descriptive statistical results of the respondents' profiles show that the majority of respondents in this study were women with an age range between 26-35 years.

Tabel 1: Respondents Profile

\begin{tabular}{|l|l|l|}
\hline \multirow{2}{*}{ Profile } & Category & $\begin{array}{l}\text { Numbers of } \\
\text { Respondents }\end{array}$ \\
\hline \multirow{3}{*}{ Gender } & Male & 61 peoples \\
\cline { 2 - 3 } & Female & 69 peoples \\
\hline \multirow{4}{*}{ Age } & $17-25$ & 33 peoples \\
\cline { 2 - 3 } & $26-35$ & 68 peoples \\
\cline { 2 - 3 } & $36-45$ & 27 peoples \\
\cline { 2 - 3 } & $46-55$ & 2 peoples \\
\hline
\end{tabular}

Source: Findings (2019)

Tabel 2: Linear Regression Result

\begin{tabular}{|l|l|l|l|l|l|l|}
\hline Model & $\mathrm{R}$ & $\mathrm{R}^{2} / \mathrm{AdjR}^{2}$ & $\mathrm{~F}_{\text {sig }}$ & Beta & $\mathrm{t}_{\text {sig }}$ & hipotesis \\
\hline WQ*EE & 0.817 & 0.667 & 0.000 & & & \\
\hline WQ & & & & 0.817 & 0.000 & $\begin{array}{l}\text { H1 } \\
\text { Supported }\end{array}$ \\
\hline WQ,EE*PE & 0.634 & 0.392 & 0.000 & & & \\
\hline WQ & & & & 0.114 & 0.342 & H2 Accepted \\
\hline EE & & & & 0.537 & 0.000 & $\begin{array}{l}\text { H3 } \\
\text { Supported }\end{array}$ \\
\hline
\end{tabular}

\section{Source: Findings (2018)}

Based on the results of simple linear regression analysis, the effect of website quality (WQ) on experience (EE) obtained an $\mathrm{R}$ value of 0.817 . This explains that there is a strong correlation. It can be concluded that the strength of the relationship between aspects of website quality (WQ) and experience (EE) is high.

R2 of 0.667 indicates that the percentage of the influence of the aspect of website quality (WQ) on experience (EE) is $66.7 \%$, while the remaining $33.3 \%$ is influenced by other variables not included in this research model, such as word of mouth, perceived usefulness, etc.

F test results indicate a significance value of 0,000 , this means that research models that aim to test the influence of aspects of website quality (WQ) on experience (EE) can be accepted. The resulting regression equation is as follows:

$\mathrm{EE}=\mathrm{b} 1 \mathrm{WS}$

$\mathrm{EE}=0.817 \mathrm{WS}$

The coefficient that is positive indicates the direct change between the independent variable and the dependent variable. So from the multiple regression equation above it can be explained that website quality (WQ) has a positive effect on experience (EE) of 0.817.

$\mathrm{t}$ test results show the hypothesis which states:

H1: Perceived website quality have significant effect on experience, is supported at level t-sig $0.000 \leq 0.05$

Based on the results of multiple linear regression analysis, the effect of website quality (WQ) and experience (EE) on performance expectancy (PE) obtained an R number of 0.634. This explains that there is a moderate 
correlation. It can be concluded that the strength of the relationship between aspects of website quality (WQ), experience (EE) and performance expectancy (PE) is medium.

R2 of 0.392 shows that the percentage of contribution of the influence of aspects of website quality (WQ) and experience (EE) on performance expectancy (PE) is $39.2 \%$, while the remaining $60.8 \%$ is influenced by other variables not included in this research model, such as for example word of mouth, perceived usefulness, etc.

F test results show a significance value of 0,000 , this means that the research model that aims to examine the influence of aspects of website quality (WQ) and experience (EE) on performance expectancy (PE) can be accepted. The resulting regression equation is as follows:

$\mathrm{PE}=\mathrm{b} 1 \mathrm{WS}+\mathrm{b} 2 \mathrm{EE}$

$\mathrm{EE}=0.114 \mathrm{WS}+0,194 \mathrm{EE}$

The coefficient that is positive indicates the direct change between the independent variable and the dependent variable. So from the multiple regression equation above, it can be explained that website quality (WQ) and experience (EE) have a positive effect on performance expectancy (PE) respectively 0.114 and 0.537 .

$\mathrm{t}$ test results show the hypothesis which states:

$\mathrm{H} 2$ : Perceived website quality have significant effect on performance expectancy, not supported at level tsig $0.342 \geq 0.05$

H3: Experience have significant effect on performance expectancy, supported at level t-sig $0.000 \leq 0.05$

\section{Discussion}

Based on the results of the study, it can be concluded that website quality has a significant effect on experience but does not significantly effect performance expectancy.

This is because the visual appeal and content of a website affect an individual's perception of the usability, enjoyment, and ease of use of the site where the visual and content are seen as a reflection of quality (van Iwaarden et al., 2004; Kim and Lee, 2014). Amorim and Loureiro (2017) state that users who believe in the quality of a website that they use, will increase their perceptions regarding the usability and performance of the website. In this case, the good and bad quality of e-commerce, will determine what the expectations of users. The more a system is considered easy to use, has organized content, can provide opportunities for interaction between users, can be easily accessed using different media, and can guarantee the privacy of its users, the users will have more expectations that e-commerce will provide experience and satisfaction the good one. There is no significant effect on performance expectancy because website quality of an ecommerce cannot directly influence performance expectancy without providing good experience.

Experience on the other hand has a significant effect on performance expectancy. Davis et al. (1992) revealed that the experiences that an individual has experienced also influence the perceived usefulness (performance expectancy) possessed by that person. Agarwal and Prasad (1999) and Jiang et al. (2000) also stated that the internet experience a person has, affects both the perceived usefulness and ease of use (performance expectancy) of the person where this ultimately affects their interest in using a system.

\section{Implication}

Based on the results of the study, it can be concluded that website quality has a significant effect on experience, and web site quality and experience have an effect on performance expectancy.

This research is in line with research conducted by Anderson (1973); Davis et al. (1992); Oliver (1993); Agarwal and Prasad (1999); Jiang et al. (2000); van Iwaarden et al. (2004); Tjiptono (2011); Kim and Lee (2014); and Loureiro and Amorim (2017).

Implications of this study indicate the importance of website quality for e-commerce service providers. This is because the visual appeal and content of a website affect an individual's perception of the usability, enjoyment, and ease of use of the site. The more a system is considered easy to use, has organized content, can provide opportunities for interaction between users, can be easily accessed using different media, and 
can guarantee the privacy of its users, the users will have more expectations that e-commerce will provide a good experience.

\section{References}

[1.] Agarwal, R \& Prasad, J. (1999). “Are Individual Differences Germane to The Acceptance of New Information Technologies?” Decision Sciences (30:2), pp. 361-391.

[2.] Agustina, P. \& Liestiawati, F.I.D. (2013). "Pengaruh Faktor UTAUT terhadap E-Retention dengan E-Satisfaction sebagai Variabel Antara (Studi pada E-Learning Karyawan PT Indo Tambangaraya Megah Tbk. Jakarta Office”. Program Studi Ilmu Administrasi Niaga FISIP, Universitas Indonesia.

[3.] Al-Qeisi, K., Dennis, C., Alamanos, E., \& Jayawardhena, C. (2014). "Website Design Quality and Usage Behavior: Unified Theory of Acceptance and Use of Technology". Journal of Business Research, 67 (11), 2282-2290.

[4.] Amorim, M., \& Loureiro, S. (2017). "Effect of Website Performance Expectancy on Customer Satisfaction Online Fashion Performance". Global Fashion Management Conference, 536-539.

[5.] Anderson, E.W., Fornell, C., \& Lehmann, D.R. (1994). "Customer Satisfaction, Market Share and Profitability: Findings from Sweden”. Journal of Marketing Vol. 58 No. 3 Hal. 53-66.

[6.] Anderson, R.E. (1973). "Consumer Dissatisfaction: The Effects of Disconfirmed Expectancy on Perceived Product Performance". Journal of Marketing Research 10, 38-44.

[7.] Chang, H.H., \& Chen, S.W. (2008). "The Impact of Online Store Environment Cues on Purchase Intention, Trust, and Perceived Risk as A Mediator". Journal Department of Business Administration, National Cheng Kung University Taiwan, 32 (6).

[8.] Davis, F.D., Bagozzi, R.P., \& Warshaw, P.R. (1992). "Extrinsic and Intrinsic Motivation to Use Computers in the Workplace". J. Appl. Soc. Psychol. 22(14), 1109-1130.

[9.] Dishaw, M.T., Brent, B., \& Strong, D.M. (2002). "Extending The Task-Technology Fit Model with Self-Efficacy Constructs". Proceedings of the 8th AMCIS - Americas Conference on Information Systems, 1021-1027.

[10.] Engel, J.E., Kegerreis, R.J., \& Blackwell, R.D. (1969). "Word-of-Mouth Communications by the Innovator". Journal of Marketing, 33, 15-19.

[11.] Engel, J.F., Blackwell, R.D., \& Miniard, P.W. (1995). Perilaku Konsumen. Jakarta: Binarupa Aksara.

[12.] Fornell, C. (1992). "A National Customer Satisfaction Barometer: The Swedish Experience". Journal of Marketing, 56, 6-21.

[13.] Frow, P. \& Payne, A. (2007). “A Strategic Framework for Customer Relationship Management”. Journal of Marketing, 69, 167-176.

[14.] Gentile, C., Spiller, N., \& Noci, G. (2007). "How to Sustain The Customer Experience: An Overview of Experience Components that Co-create Value with The Customer". European Management Journal.

[15.] Ghalandari, K., Babaeinia, L., \& Jogh, M.G.G. (2012). "Investigation of the Effect of Perceived Justice on Post-Recovery Overall Satisfaction, Post-Recovery Revisit Intention and Post-Recovery Word-of-Mouth Intention from Airline Industry in Iran: The Role of Corporate Image". World Applied Sciences Journal 18 (7), 957-970.

[16.] Jati, N.J. (2012). "Analisis Faktor-Faktor yang Mempengaruhi Minat Pemanfaatan dan Penggunaan Sistem E-Ticket (Studi Empiris pada Biro Perjalanan di Kota Semarang). Skripsi Fakultas Ekonomika dan Bisnis Universitas Diponegoro Semarang.

[17.] Jiang, J.J., Hsu, M.K., Klein, G., \& Lin, B. (2000). "E-Commerce User Behavior Model: An Empirical Study". Human Systems Management, 11 (4), 265-276.

[18.] Johnson, R. \& Marakas, G. (2000). "Research Report: The Role of Behavioral Modeling in Computer Skills Acquisition: toward Refunement of the Model". Information Systems Research, 11(4), 402-417.

[19.] Kim, Y. \& Lee, H.S. (2014). "Quality, Perceived Usefulness, User Satisfaction, and Intention to Use: An Empirical Study of Ubiquitous Personal Robot Service”. Asian Social Science, 10 (11). 
[20.] Kotler, P. \& Keller, K.L. (2009). Marketing Management. New Jersey: Pearson Prentice Hall International.

[21.] Kotler, P. \& Keller. (2007). Manajemen Pemasaran. Edisi 12 Jilid 1. Jakarta: PT Indeks.

[22.] Kotler, P. \& Lane, K. (2012). Marketing Management. New Jersey: Prentice Hall.

[23.] Kotler, P. (2002). Marketing Management. Edisi Milenium 2. Alih bahasa: Hendra Teguh, "Manajemen Pemasaran". Jakarta: Prenhailindo.

[24.] Loureiro, S.M.C \& de Araujo, C.M.B. (2014). "Luxury Values and Experience as Drivers for Consumers to Recommend and Pay More”. Journal of Retailing and Consumer Services, 21(3), 394-400.

[25.] Loureiro, S.M.C. \& Amorim, M. (2017). "Customers' Online Interaction Experiences with Fashion Brands: E-Information and E-Buying". Journal E-Business State of The Art of ICT Based Challenges and Solutions.

[26.] Loureiro, S.M.C. \& Gonzales, F.J.M. (2008). “The Importance of Quality, Satisfaction, Trust, and Image in Relation to Rural Tourist Loyalty". Journal of Travel and Tourism Marketing, 25(2), 117 136.

[27.] Lovelock, C.H. \& Wright, L.K. (2007). Manajemen Pemasaran Jasa. Jakarta: PT Indeks.

[28.] Mathwick, C. \& Malhotra, N.K.R. (2001). "The Effect of Dynamic Retail Experiences on Experiential Perceptions of Value: An Internet and Catalog Comparison”. J. Retailing, 78(1), 5160.

[29.] Meyer, C. \& Schwager, A. (2007). “Understanding Customer Experience”. Harvard Business Review.

[30.] Mowen, J.C. \& Minor, M. (2002). Perilaku Konsumen. Jakarta: Prenada Media Group.

[31.] Mowen. (1995). Perilaku Konsumen dan Komunikasi Pemasaran. Jakarta: karangan Sutisna.

[32.] Oliver, R.L. (1993). "Cognitive, Affective, and Attribute Bases of the Satisfaction Response". Journal of Consumer Research 20, 431-440.

[33.] Oliver, R.L. (1997). Satisfaction: A Behavioral Perspective on the Consumer. Boston: McGrawHill.

[34.] Olsina, L., Covella, G., \& Rossi, G. (2006). "Web Quality". Retrieved from: link.springer.com: https://link.springer.com/chapter/10.1007/3-540-28218-1_4.

[35.] Parasuraman, A., Berry, L.L., \& Zeithaml, V.A. (1990). "An Empirical Examination of Relationships in an Extended Service Quality Model". Cambridge, MA: Marketing Science Institute

[36.] Pearson, M. (2008). Sistem Informasi Manajemen. Jakarta: Salemba.

[37.] Rini, E.S. (2009). "Menciptakan Pengalaman Konsumen dengan Experiential Marketing”. Jurnal Manajemen Bisnis, 2 (1), 15-20.

[38.] Robinnete, S. \& Brand, C. (2008). Emoticon Marketing. US: McGrow Hill.

[39.] Schiffman, L.G. \& Kanuk, L.L. (2010). Consumer Behavior. New Jersey: Pearson Prestice Hall.

[40.] Shaw, C. \& Ivens, J. (2002). Building Great Customer Experience. New York: Macmillan Palgrave.

[41.] Sweeney, J.C. \& Soutar, G.N. (2001). "Consumer Perceived Value: The Development of A Multiple Item Scale”. Journal of Retailing, Vol. 77 No. 2 Hal. 203-220.

[42.] Sweeney, J.C., Soutar, G.N., \& Mazzarol, T. (2007). "Factors Influencing Word-of-Mouth Effectiveness: Receiver Perspectives". European Journal of Marketing, 42 (3/4) Pp. 344-364.

[43.] Tan M. \& Teo, T.S.H. (2000). "Factors Influencing the Adoption of Internet Banking". J. Assoc. Info. Syst. 1(5), 22-38.

[44.] Terblanche, N.S. (2009). "Customer Experiences, Interactions, Relationships and Corporate Reputation". Journal of General Management, 35 (1).

[45.] Tjiptono, F. (2008). Strategi Pemasaran. Yogyakarta: Andi Offset.

[46.] Tjiptono, F. (2011). Pemasaran Jasa. Malang: Bayumedia.

[47.] Van Iwaarden, J., Wiele, T.V.D., Ball, L., \& Millen, R. (2004). "Perceptions about the Quality of Web Sites: A Survet amongst Students at Northeastern University and Erasmus University". Journal Information and Management (41) 8, 947-959. 
[48.] Venkatesh, V., Morris, M.G., Davis, G.B. \& Davis, F.D. (2003). “User Acceptance of Information Technology: Toward A Unified View”. MIS Quarterly, (27) 3, 425-478.

[49.] Wardhana, R.E. (2016). "Pengaruh Customer Experience terhadap Loyalitas Pelanggan dengan Kepuasan Pelanggan sebagai Variabel Intervening (Studi pada Konsumen Mie Rampok Tahanan Surabaya”. Jurnal Ilmu Manajemen (4), 3.

[50.] Watkins, H. (2007). "How to Drive Loyalty through Fantastic Customer Experiences". Kae: Marketing Intelligence.

[51.] Westbrook, R.A. \& Reilly, M.D. (1983). "Value-Percept Disparity: An Alternative to the Disconfirmation of Expectations Theory of Consumer Satisfaction". Advances in Consumer Research 10, 256-261.

[52.] Wheatley, J.J., Walton, R.G., \& Chiu, J.S.Y. (1977). "The Influence of Prior Product Experience, Price, and Brand on Quality Perception". Advances in Consumer Research, 4, 72-77.

[53.] Yoo, B. \& Donthu, N. (2001). "Developing a Scale to Measure the Perceived Quality of an Internet Shopping Site (SITEQUAL)". Quarterly Journal of Electronic Commerce, 2 (1), 31-46.

[54.] Zeithaml, V. A., Parasuraman, A., \& Malhotra, A. (2012). "Service Quality Delivery through Web Sites: A Critical Review of Extant Knowledge". Journal of the Academy of Marketing Science, 30 (4), 362-375. 